\title{
論文オープンアクセスへの模索
}

\section{Open sesame}

2010 年 4 月 8 日号 Vol. 464 (813)

科学論文の無料公開を拡大しようとする政府の力が強まっている。

これに応えて、科学出版は多様化しつつある。

インターネットの普及は、一次科学文献 の出版事業を根底から覆す過激なアイデ アを生んだ。それは「論文誌が、読者や 図書館から定期購読料を徵収する代わり に、著者から掲載料を徵収すれば、世界 中の誰もが、査読論文を無料で読めるよ うになる」というものだ。

このアイデアは感情的な論争を巻き起 こし、オープンアクセスを支持する人と、 出版社・図書館・研究助成機関との間で、 さまざまな対立が生じた。しかし現在で は、「変化を避けることはできないが、 建設的な変化を生み出すためには時間と 発想と実験が必要だ」という共通認識が できつつある。

オープンアクセスの先駆者は非営利 団体 Public Library of Science (PLoS) と営利会社 BioMed Central で、著者負 担モデルでも収益を上げられることを実 証した。ただ、成功した反面、厳しい現 実も味わつている。

2003 年の PLoS 発足時の目標は、1 論文当たりの著者負担 1500 ドル（約 14 万円）で、インパクトの高い論文誌 を黒字化することだった。ところが現実 には 2900 ドル（約 26 万円）にもなっ てしまい、全体の財務状態は、電子版論 文誌 PLOS ONE に掲載される大量の論 文に大きく依存することになっている。 こちらの低コスト論文誌は、著者負担 は 1 論文当たり 1350 ドル（約 12 万円） だが、論文の価值について編集上の判断 が下されることはなく、査読を実施して、 専門的根拠に基づいた論文であることを 単に認定するだけとなっている。

課題は明確だ。Scienceや Natureなど
では、高い選択性、総説論文など付加価 值のある編集コンテンツ、またウェブサ イトの付加拡張機能などにかかる経費 を、定期購読料で賄っている。それが PLoS ONE の著者負担の数倍になるとい うことだ。したがって、著者負担モデル は、低コスト論文誌なら実行可能かもし れないが、高レベルの論文誌まで拡大さ れるかどうかはわからない。研究機関が どの程度の掲載料予算を認めるかにか かっていると思われる。

一方で、貴重な中間モデルとして確 立しているのが、ハイブリッド方式だ。 「著者が一定の料金を支払えば、その論 文を直ちに無料公開する」というオプ ションのついた論文誌である。私たちは、 Nature の姉妹誌として初めて、この夕 イプの Nature Communications を創刊 した。科学出版業を調査した経済学者が 指摘するように、この業界は、最終的に は、単一方式ではなく、オープンアクセ ス、定期購読誌、ハイブリッド誌が共存 する状態へと進化するのかもしれない。

現在、特に生物医学のような一般市民 の関心の高い分野において、文献利用の 機会拡大を求める声が大きくなってい る。立法府の議員や研究助成機関からも だ。こうした要求は、少なくとも近い将 来、別の形のオープンアクセスモデルに よって満たされる可能性が高い。2007 年に制定された米国の法律では、米国 立衛生研究所 (NIH) の研究者は、論 文を発表から 12 か月内に PubMed Central のリポジトリで公開することが 義務づけられた。オバマ大統領が、これ をすべての連邦研究機関に拡大する大統
領令を発するという観測もある（Nature 2010 年 4 月 8 日号 822 ページ参照)。 同じ趣旨の法案が米国上院に提出されて おり、まもなく下院にも提出される可能 性がある。

Nature は、これまで一貫して、公開 への動きを支持・支援してきた。ただし、 論文誌への掲載からアーカイブへの論文 寄託までの期間については、柔軟性を もたせるべきだと考える。NIH は当初、 公開制限期間を 6 か月とするよう主張 したが、一部出版社から抗議を受け 12 か月に延長した。政府は、一律の公開制 限期間を課してはならない。

現在、多くの大学図書館が大幅な経費 削減に直面している。PubMed Central のようなアーカイブで、最新のコンテン ツ以外のすべてが無料利用できれば、論 文誌の定期購読を打ち切りたい誘惑にか られるだろう。こうした事態は、社会科 学のような分野の論文誌を狙い撃ちする 危険性が高い。分子生物学など動きの速 い分野と比べて、社会科学の研究者は、 古い文献を利用する頻度がはるかに多い からだ。

出版社は、市民のアクセスを向上させ るという義務を果たしつつ、事業を危険 にさらさないよう努力し続けなければな らない。それゆえ、公開制限期間には交 渉の余地を残しておく必要がある。その 一方で、出版社は、科学と市民との間に 結ばれた社会契約が、間違いなく、公開 性を高める方向に進化していることを しっかりと認識すべきである。

(翻訳：菊川要) 